\title{
Ageing with HIV: next challenges
}

Martin Fisher

From $16^{\text {th }}$ International Symposium on HIV and Emerging Infectious Diseases

Marseille, France. 24-26 March 2010

With the advent of effective HAART and subsequent improved survival and also with ongoing HIV transmission including amongst older persons, the HIV positive population accessing care is ageing and a significant proportion of patients (up to $25 \%$ in some cohorts) are now aged over 50.

Older age has an effect on both HIV natural history and response to HAART. Older persons in the preHAART era progressed more rapidly to AIDS or death after seroconversion and AIDS diagnoses occurred at higher CD4 counts. Virological response to HAART is typically greater in older patients, likely mediated by greater levels of adherence, although immunological responses appear blunted. Some HAART toxicities occur at a higher frequency on older patients, although tolerance of adverse effects may be greater.

Additionally, it is increasingly suggested that HIV may result in accelerated ageing. This is thought to result from a combination of lifestyle factors, drug toxicities, and chronic inflammation/immune activation which persists even in the setting of virological suppression. Morbidities that were not historically considered to be HIV-related (e.g. cardiovascular disease, osteopaenia, "non-AIDS" malignancies) are now considered to be related to both ongoing HIV replication and chronic immune activation, and all are associated with increasing age.

It is therefore likely that HIV treatment recommendations (such as when to start HAART and what to start with) may need to be adapted for the older patient. Furthermore, older patients with HIV are likely to increasingly experience multiple co-morbidites which

Department of HIV and Genitourinary Medicine, Brighton and Sussex University Hospitals, Brighton, UK

BioMed Central @ 2010 Fisher, licensee BioMed Central Ltd. will require complex management and significant challenges to healthcare delivery.

Published: 11 May 2010

doi:10.1186/1742-4690-7-S1-14

Cite this article as: Fisher: Ageing with HIV: next challenges.

Retrovirology 2010 7(Suppl 1):14.
Submit your next manuscript to BioMed Central and take full advantage of:

- Convenient online submission

- Thorough peer review

- No space constraints or color figure charges

- Immediate publication on acceptance

- Inclusion in PubMed, CAS, Scopus and Google Scholar

- Research which is freely available for redistribution

Submit your manuscript at www.biomedcentral.com/submit
C Biomed Central 